Voix et Images

volXetimages

\title{
Index du volume XXIV
}

Volume 25, numéro 1 (73), automne 1999

Rêver l'enfance : Littérature et psychanalyse

URI : https://id.erudit.org/iderudit/201475ar

DOI : https://doi.org/10.7202/201475ar

Aller au sommaire du numéro

Éditeur(s)

Université du Québec à Montréal

ISSN

0318-9201 (imprimé)

1705-933X (numérique)

Découvrir la revue

Citer ce document

(1999). Index du volume XXIV. Voix et Images, 25(1), 220-221.

https://doi.org/10.7202/201475ar d'utilisation que vous pouvez consulter en ligne.

https://apropos.erudit.org/fr/usagers/politique-dutilisation/ 


\section{Index du volume XXIV}

BEA'UDOIN, Réjean, "Axes de comparaison entre deux littératures", 3, p. $480-494$.

BIRON, Michel, "Des héros très discrets", 1, p. 197-202; "Présentation", 2 , p. 243-246; "Au-delà de la rupture: "Bestiaire". de Gilles Hénault", 2, p. 310-323; "Autour de quelques morts", 2, p. 407-412; "Obscénités du roman contemporain", 3, p. 598-604.

BLAIS, Jacques, "Décadence chez Nelligan: le cas du poème "[Je veux m'éluder]" ", 2, p. 264-276.

BOURASSA, Lucie, "Le verbe, encore à incarner". Lyrisme et temporalité dans Pays sans parole", 1, p. 49-68.

BROCHU, André, "Poignée d'herbes rouges", 1, p. 203-206; "La poésie tel un tabernacle", 2, p. 413-416; "Le poète et son dieu ", 3, p. 604-608.

CARPENTIER, André, "Embrayage et modalisation dans l'incipit de la fiction fantastique brève", 1, p. 141-150.

CHAMBERLAND, Paul, "L'éclipse du verbe (être)", 1, p. 82-97.

CHASSAY, Jean-François, "Avant-propos", 1, p. 5-6; "Le progrès en question. Beaugrand et Simon face aux États-Unis", 1, p. 168-179; "Avantpropos", 2, p. 239-240 ; "Avant-propos", 3, p. 453-454.

COUTURE, François, "La libberté niche-t-elle ailleurs? L'École littéraire de Montréal, Le Terroir de 1909 et le régionalisme", 3, p. 573-585.

DELAVAUX, Céline, "Bibliographie d'Yves Préfontaine", 1, p. 123-137.

GODARD, Barbara, "Une littérature en devenir: la réécriture textuelle et le dynamisme du champ littéraire. Les écrivaines québécoises au Canada anglais", 3, p.. 495-527.

HAYNE, David M., "John Talon Lesperance et la littérature canadiennefrançaise", 3, p. 528-538.

HAYWARD, Annette, "Le Canada anglais: une invention québécoise?", 3, p. $460-479$.

HUFFMAN, Shawn, "Draguer l'identité: le camp dans $26^{\text {bis, }}$ impasse $d u$ Colonel Foisy et Ne blâmez jamais les Bédouins de René-Daniel Dubois", 3, p. 558-572. 
LAFRANCE, Geneviève, "Au seuil de la mémoire: le récit de naissance dans La créance de Jacques Ferron", 1, p. 151-167.

LAMONTAGNE, André, "Entre l'excentrique et le commémoratif ", 2, p. 421-428; "Présentation", 3, p. 457-459; "Le Canada anglais: une invention québécoise? ", 3, p. 460-479.

MAILHOT, Laurent, "Événements: de la poésie québécoise", 2, p. 247-263.

MAJOR, Robert, "Le bon usage", 1, p. 183-193; "Pourquoi se raconter", 2 , p. 399-406; "Sur Jean Éthier-Blais", 3, p. 589-598.

MALENFANT, Paul Chanel, "Du Pays sans parole à l'âge de la Parole tenue ", 1, p. 36-48.

MARCOTTE, Gilles, "Ánne Hébert: "Un bruit de soie" ", 2, p. 301-309.

MELANÇON, Benoît, "Présentation", 2, p. 243-246.

MELANÇON, Robert, "Lire, cette pratique... Lecture de "Un bon coup de guillotine" de Saint-Denys Garneau ", 2, p. 289-300.

NARDOUT-LAFARGE, Élisabeth, "Les "parnasses houleux" de Rina Lasnier ", 2, p. 324-336.

NEPVEU, Pierre, "Jean-Aubert Loranger: contours de la conscience", 2, p. $277-288$.

OUELLET, Pierre, "Présentation", 1, p. 9-11; "Entretien avec Yves Préfontaine", 1, p. 20-35; "Du haut-lieu au non-lieu: l'espace du même et de l'autre", 1, p. 69-81.

PAQUIN, Jacques, "Là où ça résiste", 2, p. 416-421.

PARÉ, François, "Hélène Dorion, hors champ", 2, p. 337-347.

POTVIN, Claudine, "Voix de femmes, voix critiques, sourds et muets", 1 , p. 193-196.

PRÉFONTAINE, Yves, "Devenir — il n'est rien d'autre (extraits inédits) ",. 1, p. $12-19$.

ROBERT, Lucie, "Le théâtre dans tous ses états", 1, p. 207-214.

ROBERTS, Katherine R., "Découvrir, fonder, survivre: les romans historiques de Laure Conan", 2, p. 351-371.

ROCHON, François, "Fatalisme et merveilleux chez Michel Tremblay. Une lecture des Chroniques du Plateau Mont-Royal", 2, p. 372-395.

SAINT-MARTIN, Lori, "L'androgynie, la peur de l'autre et les impasses de l'amour: La tourriée d'automne de Jacques Poulin", 3, p. 541-557.

SIMARD, Nicolas, "Bibliographie d'Ỵves Préfontaine", 1, p. 123-137.

VAN SCHENDEL, Michel, "De la résonance à la parole", 1, p. 98-122. 